\title{
Adrenocorticotropic hormone analog use for podocytopathies
}

This article was published in the following Dove Press journal:

International Medical Case Reports Journal

28 June 2016

Number of times this article has been viewed

\author{
Edward J Filippone' \\ Shirley J Dopson ${ }^{2}$ \\ Denise M Rivers ${ }^{3}$ \\ Rebeca D Monk ${ }^{4}$ \\ Suneel M Udani ${ }^{5}$ \\ Golriz Jafari ${ }^{6}$ \\ Solomon C Huang ${ }^{6}$ \\ Arafat Melhem ${ }^{7}$ \\ Bassim Assioun ${ }^{7}$ \\ Paul G Schmitz \\ 'Division of Nephrology, Department \\ of Medicine, Sidney Kimmel Medical \\ College at Thomas Jefferson \\ University, Philadelphia, ${ }^{2}$ Division \\ of Medicine, Washington Health \\ System, Southwestern Nephrology, \\ Inc, Washington, PA, ${ }^{3}$ Department \\ of Medicine, University Nephrology, \\ University of Tennessee, Knoxville, \\ $\mathrm{TN},{ }^{4}$ Department of Medicine, \\ Division of Nephrology, University of \\ Rochester Medical Center, Rochester, \\ NY, ${ }^{5}$ Department of Medicine, \\ Section of Nephrology, University \\ of Chicago, Chicago, IL, ' ${ }^{\circ}$ ivision of \\ Nephrology and Hypertension, Olive \\ View-University of California, Los \\ Angeles Medical Center, Sylmar, CA, \\ ${ }^{7}$ Department of Internal Medicine, \\ Division of Nephrology, Saint Louis \\ University, St Louis, MO, USA
}

Correspondence: Edward J Filippone Division of Nephrology, Department of Medicine, Sidney Kimmel Medical College at Thomas Jefferson University, 2228 South Broad Street, Philadelphia, PA 19145, USA

$\mathrm{Tel}+\mathrm{I} 2154678955$

Fax + I 2154678956

Email kidneys@comcast.net
Background: Adrenocorticotropic hormone is being increasingly studied for treatment of various glomerulopathies, most notably membranous nephropathy. Less data are available regarding its use in idiopathic nephrotic syndrome (INS) secondary to minimal change disease (MCD) or focal segmental glomerulosclerosis (FSGS). We report here our experience with H.P. Acthar ${ }^{\circledR}$ Gel (repository corticotropin injection) as first-line or subsequent therapy in patients with INS.

Methods: Data were taken from three patients with MCD and ten patients with FSGS from around the US, who were treated with Acthar Gel as initial or subsequent therapy. Treatment was solely at the discretion of the primary nephrologist without a specific protocol. A complete response (CR) was defined as final urine protein-to-creatinine ratio $<500 \mathrm{mg} / \mathrm{g}$ and a partial response (PR) as $50 \%$ decrease without rise of serum creatinine. Side effects and tolerability were noted.

Results: All three patients with MCD received Acthar Gel as second-line or later immunosuppressive (IS) therapy and all responded (one CR and two PRs). Two of the ten patients with FSGS received Acthar Gel as first-line IS therapy, while the other eight had failed multiple agents. Four of the ten patients with FSGS had responses, including two CRs and two PRs. The three patients with MCD tolerated therapy well without side effects. Five patients with FSGS tolerated therapy well, while five had various steroid-like side effects, resulting in therapy discontinuation in two patients.

Conclusion: Acthar Gel is a viable alternative IS agent for treatment of INS in patients intolerant or resistant to conventional therapy. More data are needed to better define its appropriate place.

Keywords: nephrotic syndrome, minimal change disease, focal segmental glomerulosclerosis, adrenocorticotropic hormone, ACTH, Acthar Gel

\section{Introduction}

Primary podocytopathies underlying idiopathic nephrotic syndrome (INS) include minimal change disease (MCD) and a group of histologic lesions collectively referred to as focal segmental glomerulosclerosis (FSGS). Despite similarities between the two (eg, generalized foot process effacement, circulating permeability factors, and response to corticosteroids), MCD and FSGS are considered distinct disease processes. ${ }^{1}$ Five histologic subtypes of FSGS that have variable responses to treatment, overall prognoses, and probably different pathogeneses are recognized in the recent Columbia classification. ${ }^{2}$

The initial immunosuppressive (IS) treatment of both $\mathrm{MCD}^{3}$ and the FSGS group $^{4}$ involves corticosteroids. In MCD patients who are intolerant to steroids or 
with frequently relapsing disease (either steroid dependent or steroid resistant), other IS agents have been used; these include alkylating agents, as well as calcineurin inhibitors (CNIs), mycophenolate mofetil (MMF), and rituximab. ${ }^{4-6}$ Although recommended by guidelines, ${ }^{4}$ no randomized controlled trials (RCTs) support steroid use in FSGS. In FSGS patients resistant or intolerant to steroids, RCTs do support $\mathrm{CNIs}^{7,8}$ and possibly dexamethasone with MMF. ${ }^{9}$ Rituximab has also been used. ${ }^{10}$

Adrenocorticotropic hormone (ACTH) has been known since the 1950 s to decrease both proteinuria and hyperlipidemia in INS. ${ }^{11,12}$ ACTH fell out of favor with the development of oral corticosteroids, presumably due to the need for multiple injections. Interest in ACTH for INS was renewed in 1999, when synthetic ACTH was found to effectively reduce proteinuria in patients with membranous nephropathy (MN). ${ }^{13}$ Subsequently, one small RCT in $\mathrm{MN},{ }^{14}$ as well as multiple case series and cohort studies in that and various other glomerulopathies, including MCD and FSGS, confirmed the efficacy of ACTH (porcine or a synthetic preparation). ${ }^{15-24}$ We report here our experience with 13 cases of INS (three MCD and ten FSGS) treated with H.P. Acthar ${ }^{\circledR}$ Gel (repository corticotropin injection; Mallinckrodt ARD Inc., Hazelwood, MO, USA).

\section{Methods}

We herein report a retrospective case series, collected from the USA, of patients with either MCD or idiopathic FSGS treated with the ACTH analog Acthar Gel. The Office of Human Research Institutional Review Board, Sidney Kimmel Medical College at Thomas Jefferson University, deemed this study exempt from ethical approval. Due to the retrospective nature of this study, no patient consent was required. Various nephrologists directed the care of these patients, and there was no set protocol for treatment. All patients received prior renin-angiotensin system (RAS) blockade or IS therapy at the discretion of the treating nephrologist. Baseline clinical data obtained include demographics (age, sex, and race), comorbidities, degree of proteinuria (24-hour urine or spot urine protein-to-creatinine ratio [UPCR] in milligrams per gram), serum creatinine, serum albumin, and lipid levels when available. In cases of FSGS, the histologic variant was noted if available. These biopsies were interpreted locally and were not centrally reviewed.

Patients were followed for variable periods of time. Follow-up data included serum creatinine and albumin, urine protein, and lipid levels. Minimum criteria for remission were $>50 \%$ proteinuria reduction, with stability of renal function (rise of serum creatinine $<25 \%$ ). A limited remission
(LR) had residual proteinuria still in the nephrotic range, whereas a partial remission $(\mathrm{PR})$ resulted in subnephrotic levels ( $<3,500 \mathrm{mg} / 24$ hours or $<3,500 \mathrm{mg} / \mathrm{g}$ of creatinine). Complete remission (CR) was defined as 24-hour urine protein $<500 \mathrm{mg}$ or spot urine protein $<500 \mathrm{mg} / \mathrm{g}$ creatinine, again with stable renal function. All others were considered to have no response (NR). Results are merely descriptive, as no formal statistical analysis was performed, owing to the small numbers.

\section{Results}

We identified a total of 13 patients, including three with MCD and ten with FSGS. The latter included one with glomerular tip lesion, three with collapsing FSGS, and two patients with FSGS not otherwise specified (NOS). The other four cases were not further categorized. Baseline data are detailed in Table 1. Age of onset ranged from 6 years to 73 years (mean of 39 years; median of 38 years). Eight were female and eight were Caucasian, four African American, and one Asian.

Two MCD patients were initially treated with oral prednisone $(60 \mathrm{mg} / \mathrm{d})$. One was responsive but relapsed, and the other failed to respond, in association with intolerance (worsening edema). The third MCD patient had a long history of MCD (16 years). Most recently, he was refractory to a combination of prednisone, cyclophosphamide, and MMF.

Of the ten FSGS patients, two were treated only with RAS blockade prior to Acthar Gel. Seven were treated with prednisone - either alone (patients 10 and 13) or in combination with various other IS agents (Table 1), and one was treated with only MMF. The dose of Acthar Gel ranged from $40 \mathrm{U}$ weekly to $80 \mathrm{U}$ twice weekly, with most receiving $80 \mathrm{U}$ twice weekly (Table 2). Therapy duration ranged from 1 month to 10 months, with the exception of two patients who remained on ongoing therapy, one with MCD receiving $80 \mathrm{U}$ weekly for a total duration of 17 months and one FSGS patient receiving $40 \mathrm{U}$ weekly for a total duration of 7 months. The other eleven patients received Acthar Gel with a median duration of 7 months (mean: 5.9 months) and a total dose ranging from $640 \mathrm{U}$ to 7,000 $\mathrm{U}$ (mean: $~ 3,800 \mathrm{U}$; median: $\sim 4,800 \mathrm{U}$ ) for that group. Two patients with MCD received concomitant RAS blockade, as did eight of ten patients with FSGS. Vitamin D (ergocalciferol: 50,000 U weekly) was concomitantly given to three FSGS patients, as was a statin to two MCD patients and three FSGS patients.

\section{MCD results}

All three patients with MCD had a response. Patient 1 initially responded to $60 \mathrm{mg} / \mathrm{d}$ of oral prednisone with a decrease in proteinuria from $\sim 16,000 \mathrm{mg} / \mathrm{d}$ to $400 \mathrm{mg} / \mathrm{d}$. Upon tapering 
Table I Baseline characteristics and previous therapy

\begin{tabular}{|c|c|c|c|c|c|c|c|c|c|c|c|}
\hline & $\begin{array}{l}\text { Patient } \\
\text { number }\end{array}$ & $\begin{array}{l}\text { Age, } \\
\text { years }\end{array}$ & Race & $\begin{array}{l}\text { Duration } \\
\text { prior to } \\
\text { Acthar Gel }\end{array}$ & Sex & $\begin{array}{l}\text { Proteinuria, } \\
\mathrm{mg} / \mathrm{g} \text { or } \\
\mathrm{mg} / \mathrm{d}\end{array}$ & $\begin{array}{l}\text { Serum } \\
\text { creatinine, } \\
\mathbf{m g} / \mathrm{dL}\end{array}$ & $\begin{array}{l}\text { Serum } \\
\text { albumin, } \\
\text { g/dL }\end{array}$ & $\begin{array}{l}\text { Serum } \\
\text { TC, } \\
\text { mg/dL }\end{array}$ & Initial IS therapy & $\begin{array}{l}\text { Response to } \\
\text { initial therapy }\end{array}$ \\
\hline \multirow[t]{3}{*}{ MCD } & 1 & 32 & Asian & 6 months & $\mathrm{F}$ & $16,465 \mathrm{mg} / \mathrm{d}$ & 0.84 & 0.8 & 506 & Prednisone $60 \mathrm{mg} / \mathrm{d}$ & $\mathrm{CR}$ \\
\hline & 2 & 73 & C & 6 months & M & $\begin{array}{l}4,060 \mathrm{mg} / \mathrm{d} \\
3,100 \mathrm{mg} / \mathrm{g}\end{array}$ & 1.2 & 4.1 & 159 & Prednisone $60 \mathrm{mg} / \mathrm{d}$ & NR \\
\hline & 3 & 6 & C & 16 years & M & $12,400 \mathrm{mg} / \mathrm{g}$ & 1.3 & 2.2 & NA & $\begin{array}{l}\text { Prednisone } \\
\text { Azathioprine } \\
\text { MMF } \\
\text { Cyclophosphamide }\end{array}$ & NR \\
\hline \multirow[t]{24}{*}{ FSGS } & 4 Tip & 44 & C & 6 months & $\mathrm{F}$ & $8,430 \mathrm{mg} / \mathrm{d}$ & 0.84 & 2.3 & 290 & Acthar Gel & NR \\
\hline & 5 Coll & 33 & C & 10 months & $\mathrm{F}$ & $7,920 \mathrm{mg} / \mathrm{d}$ & 0.99 & 1.9 & 404 & Prednisone $60 \mathrm{mg} / \mathrm{d}$ & $N R$ \\
\hline & & & & & & & & & & PE/Dexa/MMF & NR \\
\hline & & & & & & & & & & Abatacept & PR \\
\hline & 6 & 38 & C & 10 years & $\mathrm{F}$ & $5,800 \mathrm{mg} / \mathrm{d}$ & 1.2 & 3.3 & NA & Acthar Gel & NR \\
\hline & 7 Coll & 17 & AA & 10 months & M & $36,000 \mathrm{mg} / \mathrm{g}$ & 1.79 & 1.2 & 359 & Prednisone $60 \mathrm{mg} / \mathrm{d}$ & NR \\
\hline & & & & & & & & & & Cys A I50 mg bid & \\
\hline & $8 \mathrm{NOS}$ & 65 & C & 4 years & M & $7,700 \mathrm{mg} / \mathrm{g}$ & 1.93 & 3.6 & 189 & MMF I,500 mg bid & NR \\
\hline & 9 NOS & 19 & AA & 3 years & $\mathrm{F}$ & $16,100 \mathrm{mg} / \mathrm{g}$ & 1.48 & 2.2 & 251 & Prednisone $60 \mathrm{mg} / \mathrm{d}$ & CR \\
\hline & & & & & & & & & & Cys A I50 mg bid & CR \\
\hline & & & & & & & & & & Prednisone $60 \mathrm{mg} / \mathrm{d}$ & $P R$ \\
\hline & I0 Coll & 54 & AA & 8 months & $F$ & I I,090 mg/g & 1.34 & 2.2 & 289 & Prednisone $80 \mathrm{mg} / \mathrm{d}$ & $\begin{array}{l}\text { Initial PR, then } \\
\text { side effects }\end{array}$ \\
\hline & 11 & 52 & AA & 9 years & $\mathrm{F}$ & $6,700 \mathrm{mg} / \mathrm{g}$ & 6.3 & 1.2 & NA & Prednisone & NR \\
\hline & & & & & & & & & & Cyclophosphamide & \\
\hline & & & & & & & & & & Cys A & \\
\hline & & & & & & & & & & MMF & \\
\hline & & & & & & & & & & Tacrolimus & \\
\hline & & & & & & & & & & Rituximab & \\
\hline & 12 & 33 & C & 10 years & $\mathrm{F}$ & $3,100 \mathrm{mg} / \mathrm{g}$ & 0.9 & 3.3 & NA & Prednisone & NR \\
\hline & & & & & & & & & & Cyclophosphamide & \\
\hline & & & & & & & & & & MMF & \\
\hline & & & & & & & & & & Azathioprine & \\
\hline & & & & & & & & & & Pentoxifylline & \\
\hline & 13 & 43 & C & 4 years & M & $5,900 \mathrm{mg} / \mathrm{g}$ & 0.9 & 4.2 & NA & Prednisone & PR \\
\hline
\end{tabular}

Note: The laboratory values in this table are those obtained prior to any IS therapy.

Abbreviations: AA, African American; bid, twice daily; C, Caucasian; Coll, collapsing FSGS; CR, complete remission; Cys A, cyclosporine A; Dexa, dexamethasone; F, female; FSGS, focal segmental glomerulosclerosis; IS, immunosuppressive; M, male; MCD, minimal change disease; MMF, mycophenolate mofetil; NA, not available; NOS, FSGS not otherwise specified; NR, no response; PE, plasma exchange; PR, partial remission; TC, total cholesterol; Tip, glomerular tip lesion.

the prednisone, a marked relapse in proteinuria occurred, ultimately increasing to $84,000 \mathrm{mg} / \mathrm{d}$, which was unresponsive to increasing prednisone dosage. Twice-weekly administration of Acthar Gel, $80 \mathrm{U}$, was initiated and followed within 6 months by treatment with $80 \mathrm{U}$ weekly (which is ongoing), along with MMF 1,000 mg twice daily (bid). She remained in PR $(1,860 \mathrm{mg} / \mathrm{d})$ at her last follow-up 17 months after starting Acthar Gel. Patient 2 with MCD was initially treated with oral prednisone $60 \mathrm{mg} / \mathrm{d}$ but did not respond after 8 weeks and was intolerant (weight gain and worsening edema). Acthar Gel initiation at $80 \mathrm{U}$ twice weekly produced a PR with 6 months of therapy. Patient 3 had a 16-year history of MCD since age 6. As an adult, he was unresponsive to a regimen of prednisone, azathioprine, cyclophosphamide, and MMF. Twice-weekly administration of Acthar Gel,
$80 \mathrm{U}$, was initiated, and MMF was continued at 1,000 mg bid for 8 months. Proteinuria decreased from 12,400 mg/g to $270 \mathrm{mg} / \mathrm{g}$ for a CR. He remains on MMF.

\section{FSGS results}

Of the ten patients with FSGS, two had a CR and two a PR. Patient 5, a 33-year-old Caucasian woman, had severe nephrosis with proteinuria values that became markedly elevated (UPCR $>30,000 \mathrm{mg} / \mathrm{g}$ ), anasarca, hypoalbuminemia $(<2.0 \mathrm{~g} / \mathrm{dL})$, and hypercholesterolemia $(404 \mathrm{mg} / \mathrm{dL})$. She initially received 6 weeks of daily prednisone $(60 \mathrm{mg} / \mathrm{d})$ without response. Subsequently, plasma exchange $(\times 5)$ and dexamethasone/MMF were used for 4 months but were ineffective and discontinued because of side effects. Following a several-month hiatus, she began abatacept, $750 \mathrm{mg}$ every 
Table 2 Response to Acthar Gel

\begin{tabular}{|c|c|c|c|c|c|c|c|c|}
\hline Patient & $\begin{array}{l}\text { Acthar Gel } \\
\text { regimen }\end{array}$ & $\begin{array}{l}\text { Acthar } \\
\text { Gel } \\
\text { duration }\end{array}$ & $\begin{array}{l}\text { Follow-up } \\
\text { after Acthar } \\
\text { Gel initiation }\end{array}$ & $\begin{array}{l}\text { Concomitant } \\
\text { therapy }\end{array}$ & $\begin{array}{l}\text { Serum creatinine, } \\
\text { pre-/post-Acthar } \\
\text { Gel initiation, } \\
\text { mg/dL }\end{array}$ & $\begin{array}{l}\text { Proteinuria, } \\
\text { pre-/post- } \\
\text { Acthar Gel } \\
\text { initiation }\end{array}$ & Outcome & Adverse events \\
\hline $\mathrm{I}$ & $\begin{array}{l}80 \cup \text { twice weekly, } \\
\text { then weekly }\end{array}$ & Ongoing & 17 months & $\begin{array}{l}\text { RASB } \\
\text { Statin } \\
\text { MMF } \\
\text { I,000 mg bid }\end{array}$ & $0.7 / 0.5 \mathrm{I}$ & $\begin{array}{l}84,300 \mathrm{mg} / \mathrm{d} / \\
\mathrm{I}, 860 \mathrm{mg} / \mathrm{d}\end{array}$ & PR & None \\
\hline 2 & $80 \cup$ twice weekly & 6 months & 16 months & Statin & $1.2 / 1.39$ & $\begin{array}{l}3,119 \mathrm{mg} / \mathrm{g} / \\
918 \mathrm{mg} / \mathrm{g}\end{array}$ & PR & None \\
\hline 3 & $80 \cup$ twice weekly & 10 months & 26 months & $\begin{array}{l}\text { RASB } \\
\text { MMF }\end{array}$ & $1.3 / 1.2$ & $\begin{array}{l}12,400 \mathrm{mg} / \mathrm{g} / \\
270 \mathrm{mg} / \mathrm{g}\end{array}$ & $C R$ & None \\
\hline 4 & $40 \cup$ twice weekly & 5 months & 18 months & RASB & $0.84 / 0.9$ & $\begin{array}{l}8,430 \mathrm{mg} / \mathrm{d} / \\
10,825 \mathrm{mg} / \mathrm{d}\end{array}$ & NR & $\begin{array}{l}\text { Weight gain, myalgia, } \\
\text { worsening diabetes, } \\
\text { and hypertension }\end{array}$ \\
\hline 5 & $80 \cup$ twice weekly & 9 months & 16 months & $\begin{array}{l}\text { RASB } \\
\text { Abatacept }\end{array}$ & $3.05 / 0.83^{\mathrm{a}}$ & $\begin{array}{l}\text { Albumin/ } \\
\text { creatinine: } \\
>30,000 \mathrm{mg} / \mathrm{g} / \\
255 \mathrm{mg} / \mathrm{g}^{\mathrm{a}}\end{array}$ & $\mathrm{CR}$ & Weight gain \\
\hline 6 & $80 \cup$ twice weekly & 2 months & 16 months & RASB & 2.4/ESRD & NA & NR & $\begin{array}{l}\text { None but } \\
\text { noncompliant }\end{array}$ \\
\hline 7 & $80 \cup$ twice weekly & 10 months & 15 months & $\begin{array}{l}\text { Vitamin D } \\
\text { Statin }\end{array}$ & $2.44 / 3.61$ & $\begin{array}{l}15,700 \mathrm{mg} / \mathrm{g} / \\
2,700 \mathrm{mg} / \mathrm{g}\end{array}$ & $\begin{array}{l}\text { NR (rise in } \\
\text { creatinine) }\end{array}$ & None \\
\hline 8 & $80 \cup$ twice weekly & I month & 7 months & $\begin{array}{l}\text { RASB } \\
\text { Vitamin D } \\
\text { Statin }\end{array}$ & $3.02 / 2.3$ & $\begin{array}{l}8,400 \mathrm{mg} / \mathrm{g} / \\
15,600 \mathrm{mg} / \mathrm{g}\end{array}$ & NR & $\begin{array}{l}\text { Weight gain, } \\
\text { hypertension, } \\
\text { edema, and fatigue }\end{array}$ \\
\hline 9 & $80 \cup$ twice weekly & 3 months & 20 months & Vitamin D & $1.01 / 1.01$ & $\begin{array}{l}1,100 \mathrm{mg} / \mathrm{g} / \\
67 \mathrm{mg} / \mathrm{g}\end{array}$ & $C R$ & None \\
\hline 10 & $\begin{array}{l}40 \cup \text { twice weekly, } \\
\text { then weekly }\end{array}$ & Ongoing & 7 months & $\begin{array}{l}\text { RASB } \\
\text { Statin }\end{array}$ & I.55/I.7| & $\begin{array}{l}2,700 \mathrm{mg} / \mathrm{g} / \\
624 \mathrm{mg} / \mathrm{g}\end{array}$ & $P R$ & $\begin{array}{l}\text { Myalgia, } \\
\text { weakness, and } \\
\text { hyperpigmentation }\end{array}$ \\
\hline II & $80 \cup$ twice weekly & 7 months & 14 months & RASB & $6.3 / 6.5$ & $\begin{array}{l}6,700 \mathrm{mg} / \mathrm{g} / \\
12,800 \mathrm{mg} / \mathrm{g}\end{array}$ & NR & $\begin{array}{l}\text { Skin pigmentation, } \\
\text { weight gain, } \\
\text { worsening diabetes, } \\
\text { and Cushingoid } \\
\text { features }\end{array}$ \\
\hline 12 & $80 \cup$ twice weekly & 7 months & 17 months & RASB & $0.9 / 1.2$ & $\begin{array}{l}3,100 \mathrm{mg} / \mathrm{g} / \\
2,100 \mathrm{mg} / \mathrm{g}\end{array}$ & NR & None \\
\hline 13 & $80 \cup$ twice weekly & 7 months & 18 months & RASB & $0.9 / 1.0$ & $\begin{array}{l}5,900 \mathrm{mg} / \mathrm{g} / \\
1,700 \mathrm{mg} / \mathrm{g}\end{array}$ & PR & None \\
\hline
\end{tabular}

Note: apost-Acthar Gel initiation laboratory values for this patient are from her 7-month follow-up.

Abbreviations: CR, complete remission; ESRD, end-stage renal disease; MMF, mycophenolate mofetil; NA, not available; NR, no response; PR, partial remission; RASB, renin-angiotensin system blockade; $U$, units.

other week, with significant diuresis (biopsy noted to be B7-1 negative). Acthar Gel $80 \mathrm{U}$ twice weekly was added 2 months later, with serum creatinine at $3 \mathrm{mg} / \mathrm{dL}$. Diuresis continued with this combination. Serum creatinine decreased to $<1.0 \mathrm{mg} / \mathrm{dL}$ repeatedly, with a urine albumin/creatinine ratio of 766 by 2 months of combined therapy and 254 by 7 months. Weight loss was $\sim 20 \mathrm{~kg}$. She took Acthar Gel for 9 months. Sixteen months after starting Acthar Gel and having been off it for several months, she continued to do well; abatacept had been tapered to every other month and was being discontinued.
Patient 9, a 19-year-old African American woman, initially responded to 6 months of $60 \mathrm{mg} / \mathrm{d}$ oral prednisone (UPCR decreased from $10,000 \mathrm{mg} / \mathrm{g}$ to $210 \mathrm{mg} / \mathrm{g}$ ) and subsequently to $150 \mathrm{mg}$ bid cyclosporine (UPCR down to $58 \mathrm{mg} / \mathrm{g})$. When this was discontinued after 2 years because of abdominal pain, she relapsed (UPCR 16,000 mg/g), which partially responded to $60 \mathrm{mg} / \mathrm{d}$ oral prednisone (UPCR of $1,100 \mathrm{mg} / \mathrm{g}$ ). After 2 months, prednisone was stopped and Acthar Gel begun, $80 \mathrm{U}$ twice weekly for 3 months, with a CR (UPCR of $67 \mathrm{mg} / \mathrm{g}$ ). She has remained in CR on tacrolimus $3.5 \mathrm{mg}$ bid for $>1$ year. 
As noted, two patients had a PR. Patient 10, a 54-year-old African American woman, with a UPCR of 11,000 mg/g, initially had a PR to 4 weeks of $80 \mathrm{mg} / \mathrm{d}$ oral prednisone (UPCR of 2,700 mg/g). Due to side effects (mood changes and facial puffiness), Acthar Gel was substituted (40 U twice weekly) for 6 months, with further response (UPCR of $624 \mathrm{mg} / \mathrm{g}$ ). Therapy remains ongoing. Patient 13 is a 43-year-old Caucasian man with a 4-year history of nephrotic-range proteinuria $(5,900 \mathrm{mg} / \mathrm{g})$ without nephrotic syndrome (albumin $4.2 \mathrm{~g} / \mathrm{dL}$ ). Although refractory to highdose oral steroids, he had a near-CR with Acthar Gel (UPCR of $600 \mathrm{mg} / \mathrm{g}$ ).

Six FSGS patients had NR. Patient 4 is a 44-year-old Caucasian female with glomerular tip lesion (GTL). Acthar Gel was the initial IS treatment at $40 \mathrm{U}$ twice weekly for 5 months. Treatment was discontinued due to side effects (myalgia, weight gain, and worsening diabetes) without remission. Repeat biopsy confirmed GTL, and subsequent treatments with MMF 1,000 mg bid followed by cyclosporine $50 \mathrm{mg}$ bid were also ineffective. Patient 6, a 38-year-old Caucasian female, presented with a 10-year history of nephrosis. After noncompliance with oral steroids, she received $80 \mathrm{U}$ Acthar Gel twice weekly, which was stopped after 2 months due to declining glomerular filtration rate. Dialysis was initiated 1 month later. Patient 7, a 17-year-old African American man, presented with collapsing FSGS. He was treated initially with prednisone $60 \mathrm{mg} / \mathrm{d}$, with reduction of UPCR from $36,000 \mathrm{mg} / \mathrm{g}$ to $12,800 \mathrm{mg} / \mathrm{g}$ after 4 months. This was followed by cyclosporine $150 \mathrm{mg}$ bid, with no improvement in proteinuria (UPCR increased to $15,700 \mathrm{mg} / \mathrm{g}$ ). Acthar Gel was then prescribed at $80 \mathrm{U}$ twice weekly, with proteinuria decreasing to a UPCR of $2,700 \mathrm{mg} / \mathrm{g}$, but the case was deemed an NR due to rising serum creatinine (from $2.44 \mathrm{mg} / \mathrm{dL}$ to $3.61 \mathrm{mg} / \mathrm{dL}$ ). Patient 8 was a 65 -year-old Caucasian man with FSGS NOS. Initial IS treatment was MMF 1,500 mg bid for 10 months, with no improvement in UPCR $(7,700 \mathrm{mg} / \mathrm{g}$ to $8,400 \mathrm{mg} / \mathrm{g}$ ), although serum creatinine was reduced from $3.02 \mathrm{mg} / \mathrm{dL}$ to $2.3 \mathrm{mg} / \mathrm{dL}$. A twice-weekly dose of Acthar Gel, $80 \mathrm{U}$, was initiated and continued for 1 month, with NR. Treatment was discontinued due to side effects (worsening edema and hypertension). Patient 11, a 52-year-old African American female, presented with advanced disease (serum creatinine $6.3 \mathrm{mg} / \mathrm{dL}$ ). There was NR to 7 months of the ACTH preparation (serum creatinine $6.5 \mathrm{mg} / \mathrm{dL}$; UPCR increasing from $6,700 \mathrm{mg} / \mathrm{g}$ to $12,800 \mathrm{mg} / \mathrm{g}$ ). Patient 12 , a 33-year-old Caucasian female, had a reduction of proteinuria after 7 months of Acthar Gel, from a UPCR of $3,100 \mathrm{mg} / \mathrm{g}$ to $2,100 \mathrm{mg} / \mathrm{g}$, a reduction of $<50 \%$.
Acthar Gel was reasonably well tolerated. The three patients with MCD had no side effects. Four patients with FSGS had no side effects, as did another who was noncompliant, however, with a short course (2 months) prior to end-stage renal disease. The other five patients had various, predominantly steroid-like, adverse effects, including weight gain $(n=4)$, myalgias $(n=2)$, worsening diabetes $(n=2)$, increased skin pigmentation $(n=2)$, and hypertension $(n=2)$, as well as edema and fatigue $(n=1$ each). Two patients discontinued Acthar Gel because of the side effects.

\section{Discussion}

This retrospective case series confirms the potential utility of Acthar Gel in patients with INS from a primary podocytopathy (MCD or FSGS) when resistant or intolerant to conventional therapy. All three patients with MCD responded (two PR and one CR), as did four of ten patients with FSGS (two CR and two PR).

Acthar Gel remains the only US Food and Drug Administration-approved ACTH preparation for remission of proteinuria in nephrotic syndrome, with $>50$ years of history. Originally used for pediatric INS in the 1950s, this practice was supplanted with the development of oral steroids. Currently, two long-acting ACTH preparations are available. ${ }^{25}$ In Europe, synthetic ACTH ( $N$-terminal peptide $\left.\mathrm{ACTH}_{1-24}\right)$ is available, while in the USA, the only available preparation, Acthar Gel, is a highly purified, porcine-derived whole ACTH (Mallinckrodt ARD Inc., Hazelwood, MO, USA); Acthar Gel contains $\mathrm{ACTH}_{1-39}$, along with other proopiomelanocortin (POMC) peptides. ${ }^{25,26}$ The synthetic preparation lacks the $C$-terminal 15 amino acids, which are included in the $\mathrm{ACTH}_{18-39}$ fragment. These two preparations also differ in their half-lives, as well as in posttranslational modifications. ${ }^{26}$ They have not been compared in any trial.

Long-acting ACTH has a well-known lipolytic effect when given to people with normal kidney function or patients with kidney disease (as documented in studies by Berg and Nilsson-Ehle ${ }^{27,28}$ with synthetic ACTH). Berg et al ${ }^{13}$ studied 14 patients with hyperlipidemia and nephrotic syndrome from MN using synthetic ACTH. Surprisingly, proteinuria was markedly reduced, with improved serum albumin and glomerular filtration rate. ${ }^{13}$ Subsequently, ten more case series/cohort studies ${ }^{15-24}$ of ACTH use in various glomerulopathies have been published, along with one $\mathrm{RCT}^{14}$ and four case reports ${ }^{29-32}$ (Table 3); overall, $\sim 100$ patients with $\mathrm{MN}$ received ACTH, with well $>50 \%$ responding. Most had failed $\geq 2$ prior therapies. Approximately $60 \%$ were treated with synthetic ACTH and 40\% with Acthar Gel. More than 
Table 3 Case series, cohort studies, and case reports of various glomerulopathies treated with ACTH preparations

\begin{tabular}{|c|c|c|c|c|c|c|c|c|c|}
\hline Study & Preparation & $\mathbf{M N}$ & FSGS & MCD & DN & IgAN & MPGN & Other & Discontinued due to AEs \\
\hline Berg et $\mathrm{al}^{13}$ & $\mathrm{~T}$ & $9 / 5^{a}(5)^{b}$ & & & & & & & $0 / 5$ \\
\hline Berg and Arnadottir ${ }^{16}$ & $\mathrm{~T}$ & $10(10)$ & $\mathrm{I}(\mathrm{I})$ & $2(2)$ & $2(2)$ & & $6(6)$ & $2(1)$ & $0 / 23$ \\
\hline Picardi et al ${ }^{15}$ & $\mathrm{~T}$ & $7(5)$ & & & & & & & $2 / 7$ \\
\hline Ponticelli et al ${ }^{14}$ & $\mathrm{~T}$ & $16(14)$ & & & & & & & $2 / 16$ \\
\hline Rauen et $\mathrm{al}^{17}$ & $\mathrm{~T}$ & $4(4)$ & & & & & & & $0 / 4$ \\
\hline Lindskog et al ${ }^{18}$ & $\mathrm{~T}$ & $5(4)$ & & & & & & & $0 / 5$ \\
\hline Bomback and & Gel & II (9) & $I(I)^{c}$ & I (0) & & I & $4(0)$ & 3 & $0 / 21$ \\
\hline \multicolumn{10}{|l|}{ Radhakrishnan $^{19}$} \\
\hline Bomback et a ${ }^{20}$ & Gel & $5(2)$ & $3(1)^{c}$ & $2(1)$ & & 5 & & & $3 / 15$ \\
\hline Hogan et $\mathrm{a}^{21}$ & Gel & & $24(7)$ & & & & & & $0 / 24$ \\
\hline Tumlin et $\mathrm{a}^{22}$ & Gel & & & & $14(8)$ & & & & 9 of 23 initially randomized \\
\hline Hladunewich et $\mathrm{a}^{23}$ & Gel & $20(12)$ & & & & & & & $0 / 20$ \\
\hline Lorusso et $\mathrm{al}^{24}$ & $\mathrm{~T}$ & $9(4)$ & $2(2)$ & $2(1)$ & & & $2(1)$ & & I of I8 initially randomized \\
\hline Gigante et $\mathrm{a}^{29, \mathrm{e}}$ & $\mathrm{T}$ & $I(I)$ & & & & & & & \\
\hline Watson ${ }^{30, \mathrm{e}}$ & Gel & $\mathrm{I}(\mathrm{I})$ & & & & & & & \\
\hline Anwar et $\mathrm{al}^{31, \mathrm{e}}$ & Gel & & I (I) & & & & & & \\
\hline Madan $32, \mathrm{e}$ & Gel & & I (I) & & & & & & \\
\hline This study & Gel & & $10(4)$ & $3(3)$ & & & & & $2 / 13$ \\
\hline Total & & 94 & 39 & 10 & 16 & 6 & 12 & 5 & \\
\hline Overall response & & 67 (7।\%) & I6 (4I\%) & 7 (70\%) & 10 (63\%) & & 7 (58\%) & & \\
\hline
\end{tabular}

Notes: aFive were treated for I year and are included in the overall total, nine just for the short term; boverall number attaining complete or partial remission in parentheses; cincluded among the study of Hogan et $\mathrm{l}^{21}$ and not counted separately in total; dincludes one withdrawing due to need for injections and two with scheduling conflicts; eisolated case reports.

Abbreviations: ACTH, adrenocorticotropic hormone; AEs, adverse events; DN; diabetic nephropathy; FSGS, focal segmental glomerulosclerosis; Gel, Acthar Gel; Ig, immunoglobulin; IgAN, IgA nephropathy; MCD, minimal change disease; MN, membranous nephropathy; MPGN, membranoproliferative glomerulonephritis; T, tetracosactide (long-acting), $\mathrm{ACTH}_{1-24}$.

30 patients with FSGS were given ACTH (mostly Acthar Gel), with $\sim 40 \%$ responding. Only seven with MCD have been reported, culled from four separate series.

Hogan et $\mathrm{al}^{21}$ described in detail the response to Acthar Gel in 24 patients with FSGS (eleven with tip variant) at two academic centers, using predominantly a 16 -week course (2,160 U total) in 12 patients or a 24 -week course $(3,840 \mathrm{U})$ in seven patients; five others were heterogeneously treated. A trend (not significant) to reduced proteinuria (median of $4,595 \mathrm{mg} / \mathrm{g}$ reduced to $2,243 \mathrm{mg} / \mathrm{g}$ creatinine) was seen, with no change in serum creatinine or estimated glomerular filtration rate. Seven patients responded, two $\mathrm{CR}$ and five PR, with median times to proteinuria reduction of 5 weeks (range: 2-16 weeks) and to remission of 16 weeks (range: 5-18 weeks). Five had sustained remission, and two relapsed, although two nonrelapsers were on additional IS therapy. This response rate of $29 \%$ is similar to that obtained in an FSGS RCT conducted by the National Institutes of Health (NIH), ${ }^{33}$ which compared CNI with MMF/dexamethasone in patients with resistant FSGS (with at least a PR obtained by 1 year in $46 \%$ of patients on cyclosporine and $33 \%$ of patients on MMF). Our overall response rate in FSGS was $40 \%$, similar to the results of Hogan et $\mathrm{al}^{21}$ and the NIH trial. ${ }^{33}$
It is not certain how both Acthar Gel and synthetic ACTH exert their beneficial effect in glomerulonephritis. Following a single injection of synthetic ACTH, there is a bolus of endogenous cortisol production equivalent to $50 \mathrm{mg}$ of cortisol given orally three times over 24 hours. ${ }^{34}$ It is unlikely that this degree of steroid exposure twice weekly would be efficacious in a disease such as $\mathrm{MN}$, which is not responsive to corticosteroid monotherapy ${ }^{35}$ or in resistant FSGS. Perhaps there is a differential effect of endogenously produced corticosteroids compared to that of exogenous agents, ${ }^{13}$ although no substantial proof to support this concept is available.

ACTH is derived from the cleavage of POMC produced by the anterior pituitary. ${ }^{26}$ Other cleavage products of POMC, or of ACTH itself, include three melanocyte-stimulating hormones (MSHs): $\alpha, \beta$, and $\gamma$. ACTH and these MSHs are collectively called melanocortins and are capable of activating at least five known melanocortin receptors (MCRs), termed MC1R to MC5R. Only ACTH can activate MC2R on adrenal cells to produce corticosteroids. The other four MCRs are widely expressed in various tissues, including the skin (melanocytes), kidneys, brain, exocrine glands, and various inflammatory cells, such as monocytes and lymphocytes.

ACTH is capable of stimulating all five MCRs and hence may have anti-inflammatory effects through various 
mechanisms beyond enhanced cortisol production. ${ }^{26}$ In general, activation of the four MCRs other than MC2R is anti-inflammatory. MCRs are expressed on human leukocytes, including monocytes and macrophages, as well as B-lymphocytes, CD4+ T-helper cells, and natural killer cells. ${ }^{36,37}$ Hence, melanocortins may affect cytokine production, including the potential permeability factors proposed to underlie FSGS and MCD. Melanocortins downregulate nuclear factor (NF)- $\mathrm{KB}$ activation, which is relevant to treatment of podocytopathies. ${ }^{25,38}$ The peripheral blood mononuclear cells of MCD patients in relapse have been shown to have increased nuclear NF- $\mathrm{KB}$ binding, with reduction of both mRNA and protein expression of the inhibitory Iк-B. ${ }^{39}$ Furthermore, stimulation of MCRs by ACTH in the brain may activate the anti-inflammatory pathway that is mediated by the release of acetylcholine due to vagal nerve stimulation. ${ }^{40}$ Nicotinic acetylcholine receptor activation on tissue macrophages inhibits release of inflammatory mediators, eg, tumor necrosis factor- $\alpha$ (which produces potent NF- $\kappa B$ stimulation) and interleukin-1. ${ }^{41}$

Importantly, MCRs are expressed in the kidney, and ACTH and other melanocortins may have direct podocyte-protective effects. Lindskog et a $1^{18}$ demonstrated MC1R mRNA expression in all three cell types in normal human glomeruli as well as in tubules, which contrasts with prior work demonstrating strong $M C 5 R$ complementary DNA kidney expression. ${ }^{42}$ Lindskog et $\mathrm{al}^{18}$ also showed that MC1R protein was expressed in glomeruli, specifically in podocytes, by colocalization with synaptopodin, although not in endothelial cells. Furthermore, in the passive Heymann nephritis (PHN) model of MN in rats, synthetic $\mathrm{ACTH}$, as well as $\alpha-\mathrm{MSH}$ and the specific MC1R agonist MS05, ameliorated proteinuria, hypoalbuminemia, and hypertension. ${ }^{18}$ Ultrastructural podocyte morphology was improved, and oxidative stress was reduced. In a subsequent study, Lindskog Jonsson et al ${ }^{43}$ confirmed the benefit of MS05 in PHN, with reduction of proteinuria and improved podocyte morphology.

In contrast, Qiao et $\mathrm{al}^{44}$ found a nonsteroidogenic melanocortin pan agonist to be equally effective in reducing proteinuria and ameliorating podocyte ultrastructural changes in $M C 1 R$-mutant and wild-type mice exposed to lipopolysaccharide or adriamycin. They also reported complete remissions with ACTH in two patients with mutated $M C 1 R$ (congenital red hair) and refractory $\mathrm{MN} .{ }^{44} \mathrm{In}$ a mouse model of experimental FSGS (adriamycin nephrosis), neither a MC1R agonist nor $\alpha$-MSH had any beneficial effect on proteinuria or morphology. ${ }^{43}$ In comparison, a significant beneficial effect of Acthar Gel was found in a model of secondary FSGS (nephron reduction), ${ }^{45}$ even though corticosteroids are known to exacerbate injury in this model. ${ }^{46}$ Hence, the exact mechanism of action of ACTH in MN and other glomerulopathies remains uncertain.

In an analogous manner, a direct effect on podocytes, apparently independent from immunosuppression, may also be obtained with other agents effective in INS, including steroids, cyclosporine, and rituximab. Studying differentiated human podocytes in vitro, Xing et $\mathrm{al}^{47}$ demonstrated that dexamethasone upregulated glucocorticoid receptor expression, accelerated podocyte maturation, increased the production of nephrin and tubulin- $\alpha$, and prolonged podocyte survival. Faul et $\mathrm{a}^{48}$ showed that cyclosporine A directly inhibits the dephosphorylation and degradation of synaptopodin, which is mediated by podocyte calcineurin, a requirement for the maintenance of the normal actin cytoskeleton. Fornoni et $\mathrm{a}^{19}$ demonstrated reduced sphingomyelin phosphodiesterase acid-like 3b (SMPDL-3b) mRNA and protein expression in podocytes of transplant patients with recurrent FSGS compared to those with nonrecurrent disease. Rituximab restored this expression compared to nontreated patients, resulting in a reduction of stress fiber disruption, an effect that correlated with the degree of proteinuria. In vitro, rituximab reduced apoptosis of podocytes that were exposed to the serum of recurrent FSGS patients. Rituximab was shown to specifically bind to SMPDL-3b in the absence of any detectable podocyte CD20, ${ }^{49}$ indicating a direct effect independent from $\mathrm{CD} 20$ binding or B-cell depletion.

Acthar Gel was reasonably well tolerated in our patients. The majority of side effects were steroid related and not severe. Two patients, however, discontinued Acthar Gel due to side effects (patients 4 and 8). Similar adverse events (AEs) were noted in the other studies cited herein, with no obvious difference noted between synthetic ACTH and Acthar Gel. These include various central nervous system effects (mood change, insomnia, and tremulousness), worsening glucose and blood pressure control, weight gain, skin changes, and myalgias. A minority of patients could not complete the planned treatment course because of various reasons, including side effects: two of seven in the case series of Picardi et al, ${ }^{15}$ two of 16 in the Ponticelli et al RCT, ${ }^{14}$ three of 15 in the prospective study of Bomback et al, ${ }^{20}$ and nine of 23 in the diabetic nephropathy trial ${ }^{22}$ (Table 3 ). Hogan et $\mathrm{al}^{21}$ reported 52 AEs ( 23 steroid-like) in 21 of 24 FSGS patients.

Our study has obvious limitations, especially the small size. It is a retrospective case series collected from various nephrology practices. Biopsies were not reviewed centrally, and the histologic subtype of FSGS was not available in some 
cases. There was no specific protocol for either initial IS therapy or for the use of Acthar Gel (dose or duration), and concomitant therapy was variable. Follow-up was relatively short and also variable in length.

\section{Conclusion}

In conclusion, our data add further support for the potential use of Acthar Gel in INS due to a primary podocytopathy (MCD or FSGS) in patients intolerant or resistant to, or reluctant to use, corticosteroids or other second- and third-line agents. Remission occurred in all three MCD patients and in four of ten FSGS patients. These results, along with those culled from the literature review, compare favorably with the effects of other available agents. Hopefully, RCTs using Acthar Gel will determine appropriate patients, regimens, and durations of therapy in terms of safety and effectiveness.

\section{Acknowledgments}

Funding to support the preparation of the manuscript was provided by Mallinckrodt ARD Inc. to MedVal Scientific Information Services, LLC, Skillman, NJ, USA. This manuscript was prepared according to the International Society for Medical Publication Professionals" "Good Publication Practice for Communicating Company-Sponsored Medical Research: The GPP2 Guidelines."

\section{Disclosure}

EJF has been on speakers' bureau/has received lecture fees from Mallinckrodt ARD Inc. SMU has received speaker honoraria from Mallinckrodt ARD Inc. The other authors report no conflicts of interest in this work.

\section{References}

1. Meyrier AY. Treatment of focal segmental glomerulosclerosis with immunophilin modulation: when did we stop thinking about pathogenesis? Kidney Int. 2009;76(5):487-491.

2. D'Agati VD, Fogo AB, Bruijn JA, Jennette JC. Pathologic classification of focal segmental glomerulosclerosis: a working proposal. Am J Kidney Dis. 2015;43(2):368-382.

3. Hogan J, Radhakrishnan J. The treatment of minimal change disease in adults. J Am Soc Nephrol. 2013;24(5):702-711.

4. Beck L, Bomback AS, Choi MJ, et al. KDOQI US commentary on the 2012 KDIGO clinical practice guideline for glomerulonephritis. Am J Kidney Dis. 2015;62(3):403-441.

5. Iijima K, Sako M, Nozu K, et al. Rituximab for childhood-onset, complicated, frequently relapsing nephrotic syndrome or steroid-dependent nephrotic syndrome: a multicentre, double-blind, randomised, placebocontrolled trial. Lancet. 2014;384(9950):1273-1281.

6. Bruchfeld A, Benedek S, Hilderman M, Medin C, Snaedal-Jonsdottir S, Korkeila M. Rituximab for minimal change disease in adults: long-term follow-up. Nephrol Dial Transplant. 2014;29(4):851-856.

7. Cattran DC, Appel GB, Hebert LA, et al. A randomized trial of cyclosporine in patients with steroid-resistant focal segmental glomerulosclerosis. North America Nephrotic Syndrome Study Group. Kidney Int. 1999;56(6):2220-2226
8. Braun N, Schmutzler F, Lange C, Perna A, Remuzzi G, Willis NS. Immunosuppressive treatment for focal segmental glomerulosclerosis in adults. Cochrane Database Syst Rev. 2008;(3):CD003233.

9. Canetta PA, Radhakrishnan J. Impact of the national institutes of health focal segmental glomerulosclerosis (NIH FSGS) clinical trial on the treatment of steroid-resistant FSGS. Nephrol Dial Transplant. 2013;28(3):527-534.

10. Gulati A, Sinha A, Jordan SC, et al. Efficacy and safety of treatment with rituximab for difficult steroid-resistant and -dependent nephrotic syndrome: multicentric report. Clin J Am Soc Nephrol. 2010;5(12): 2207-2212.

11. Rapoport M, McCrory WW, Barbero G, Barnett HL, Forman CW. Effect of corticotropin $(\mathrm{ACTH})$ on children with the nephrotic syndrome. JAm Med Assoc. 1951;147(12):1101-1106.

12. Barnett HL. Effect of ACTH in children with the nephrotic syndrome. Pediatrics. 1952;9(3):341.

13. Berg A, Nilsson-Ehle P, Arnadottir M. Beneficial effects of ACTH on the serum lipoprotein profile and glomerular function in patients with membranous nephropathy. Kidney Int. 1999;56(4):1534-1543.

14. Ponticelli C, Passerini P, Salvadori M, et al. A randomized pilot trial comparing methylprednisolone plus a cytotoxic agent versus synthetic adrenocorticotropic hormone in idiopathic membranous nephropathy. Am J Kidney Dis. 2006;47(2):233-240.

15. Picardi L, Villa G, Galli F, et al. ACTH therapy in nephrotic syndrome induced by idiopathic membranous nephropathy. Clin Nephrol. 2004;62(5):403-404.

16. Berg A, Arnadottir M. ACTH-induced improvement in the nephrotic syndrome in patients with a variety of diagnoses. Nephrol Dial Transplant. 2004;19(5):1305-1307.

17. Rauen T, Michaelis A, Floege J, Mertens PR. Case series of idiopathic membranous nephropathy with long-term beneficial effects of ACTH peptide 1-24. Clin Nephrol. 2009;71(6):637-642.

18. Lindskog A, Ebefors K, Johansson ME, et al. Melanocortin 1 receptor agonists reduce proteinuria. J Am Soc Nephrol. 2010;21(8): $1290-1298$.

19. Bomback AS, Radhakrishnan J. Treatment of nephrotic syndrome with adrenocorticotropic hormone (ACTH). Discov Med. 2011; 12(63):91-96.

20. Bomback AS, Canetta PA, Beck LH Jr, Ayalon R, Radhakrishnan J, Appel GB. Treatment of resistant glomerular diseases with adrenocorticotropic hormone gel: a prospective trial. Am J Nephrol. 2012; 36(1):58-67.

21. Hogan J, Bomback AS, Mehta K, et al. Treatment of idiopathic FSGS with adrenocorticotropic hormone gel. Clin J Am Soc Nephrol. 2013;8(12):2072-2081.

22. Tumlin JA, Galphin CM, Rovin BH. Advanced diabetic nephropathy with nephrotic range proteinuria: a pilot study of the long-term efficacy of subcutaneous ACTH gel on proteinuria, progression of CKD, and urinary levels of VEGF and MCP-1. J Diabetes Res. 2013;2013: 489869.

23. Hladunewich MA, Cattran D, Beck LH, et al. A pilot study to determine the dose and effectiveness of adrenocorticotrophic hormone (H.P. Acthar ${ }^{\mathbb{B}} \mathrm{Gel}$ ) in nephrotic syndrome due to idiopathic membranous nephropathy. Nephrol Dial Transplant. 2014;29(8):1570-1577.

24. Lorusso P, Bottai A, Mangione E, Innocenti M, Cupisti A, Egidi MF. Low-dose synthetic adrenocorticotropic hormone-analog therapy for nephrotic patients: results from a single-center pilot study. Int J Nephrol Renovasc Dis. 2015;8:7-12.

25. Gong R. The renaissance of corticotropin therapy in proteinuric nephropathies. Nat Rev Nephrol. 2012;8(2):122-128.

26. Gong R. Leveraging melanocortin pathways to treat glomerular diseases. Adv Chronic Kidney Dis. 2014;21(2):134-151.

27. Berg AL, Nilsson-Ehle P. Direct effects of corticotropin on plasma lipoprotein metabolism in man - studies in vivo and in vitro. Metabolism. 1994;43(1):90-97.

28. Berg A, Nilsson-Ehle P. ACTH lowers serum lipids in steroid-treated hyperlipemic patients with kidney disease. Kidney Int. 1996;50(2): $538-542$. 
29. Gigante A, Rosato E, Liberatori M, et al. ACTH and azathioprine: antiproteinuric and lipid-lowering effect in the course of idiopathic membranous glomerulonephritis. J Biol Regul Homeost Agents. 2012;26(1):135-138.

30. Watson MJ. Membranous glomerulopathy and treatment with Acthar ${ }^{\circledR}$ : a case study. Int J Nephrol Renovasc Dis. 2013;6:229-232.

31. Anwar S, Larson DS, Naimi N, et al. A case report of adrenocorticotropic hormone to treat recurrent focal segmental glomerular sclerosis post-transplantation and biomarker monitoring. Front Med (Lausanne). 2015;2:13

32. Madan A. Repository corticotropin injection in a patient presenting with focal segmental glomerulosclerosis, rheumatoid arthritis, and optic neuritis: a case report. Int J Gen Med. 2015;8:119-124.

33. Gipson DS, Trachtman H, Kaskel FJ, et al. Clinical trial of focal segmental glomerulosclerosis in children and young adults. Kidney Int. 2011;80(8):868-878.

34. Berg A, Rafnsson AT, Johannsson M, Dallongeville J, Arnadottir M. The effects of adrenocorticotrophic hormone and an equivalent dose of cortisol on the serum concentrations of lipids, lipoproteins, and apolipoproteins. Metabolism. 2006;55(8):1083-1087.

35. Filippone EJ. Immunosuppressive treatment of idiopathic membranous nephropathy: the dilemma continues. Clin Nephrol. 2013;79(2): 143-153.

36. Andersen GN, Hägglund M, Nagaeva O, et al. Quantitative measurement of the levels of melanocortin receptor subtype 1,2, 3 and 5 and pro-opio-melanocortin peptide gene expression in subsets of human peripheral blood leucocytes. Scand J Immunol. 2005;61(3):279-284.

37. Cooper A, Robinson SJ, Pickard C, Jackson CL, Friedmann PS, Healy E. $\alpha$-melanocyte-stimulating hormone suppresses antigen-induced lymphocyte proliferation in humans independently of melanocortin 1 receptor gene status. J Immunol. 2005;175(7):4806-4813.

38. Catania A, Gatti S, Colombo G, Lipton JM. Targeting melanocortin receptors as a novel strategy to control inflammation. Pharmacol Rev. 2004;56(1):1-29.
39. Sahali D, Pawlak A, Gouvello SL, et al. Transcriptional and posttranscriptional alterations of $\mathrm{I} \kappa \mathrm{B} \alpha$ in active minimal-change nephrotic syndrome. J Am Soc Nephrol. 2001;12(8):1648-1658.

40. Guarini S, Cainazzo MM, Giuliani D, et al. Adrenocorticotropin reverses hemorrhagic shock in anesthetized rats through the rapid activation of a vagal anti-inflammatory pathway. Cardiovasc Res. 2004;63(2):357-365.

41. Tracey KJ. The inflammatory reflex. Nature. 2002;420(6917): 853-859.

42. Chhajlani V. Distribution of cDNA for melanocortin receptor subtypes in human tissues. Biochem Mol Biol Int. 1996;38(1):73-80.

43. Lindskog Jonsson A, Granqvist A, Elvin J, Johansson ME, Haraldsson B, Nystrom J. Effects of melanocortin 1 receptor agonists in experimental nephropathies. PLoS One. 2014;9(1):e87816.

44. Qiao Y, Berg A, Ge Y, Liu Z, Gong R. Melanocortin 1 receptor (MC1R) is dispensable for the proteinuria reducing and glomerular protective effect of melanocortin therapy. J Am Soc Nephrol. 2015;26:64A.

45. Gong R, Dworkin LD. ACTH (Acthar gel) prevents proteinuria and renal injury in the remnant kidney. Evidence for direct podocyte protection. J Am Soc Nephrol. 2010;21:548A.

46. Garcia DL, Rennke HG, Brenner BM, Anderson S. Chronic glucocorticoid therapy amplifies glomerular injury in rats with renal ablation. $J$ Clin Invest. 1987;80(3):867-874.

47. Xing C, Saleem MA, Coward RJ, Ni L, Witherden IR, Mathieson PW. Direct effects of dexamethasone on human podocytes. Kidney Int. 2006;70(6):1038-1045.

48. Faul C, Donnelly M, Merscher-Gomez S, et al. The actin cytoskeleton of kidney podocytes is a direct target of the antiproteinuric effect of cyclosporine A. Nat Med. 2008;14(9):931-938.

49. Fornoni A, Sageshima J, Wei C, et al. Rituximab targets podocytes in recurrent focal segmental glomerulosclerosis. Sci Transl Med. 2011;3(85):85ra46.
International Medical Case Reports Journal

\section{Publish your work in this journal}

The International Medical Case Reports Journal is an international, peer-reviewed open-access journal publishing original case reports from all medical specialties. Previously unpublished medical posters are also accepted relating to any area of clinical or preclinical science. Submissions should not normally exceed 2,000 words or

\section{Dovepress}

4 published pages including figures, diagrams and references. The manuscript management system is completely online and includes a very quick and fair peer-review system, which is all easy to use. Visit http://www.dovepress.com/testimonials.php to read real quotes from published authors. 